\title{
PELAKSANAAN ASIMILASI DALAM PEMBINAAN ANAK NEGARA DI LEMBAGA PEMASYARAKATAN KARANGASEM
}

\author{
I Made Satya Adhi Wicaksana, I Made Minggu Widyantara, I Pt Gd Seputra \\ Fakultas Hukum Universitas Warmadewa, Denpasar-Bali, Indonesia
}

\begin{abstract}
Abstrak
Asimilasi mewujudkan prinsip pemasyarakatan yang menghendaki agar narapidana tidak dipisahkan dari masyarakat. Asimilasi ini diberikan dengan tujuan agar dapat memberikan pembinaan bagi narapidana, memberikan ketrampilan atau pendidikan bagi narapidana guna mempersiapkan diri hidup mandiri ditengah masyarakat setelah bebas menjalani pidana. Asimilasi dapat memungkinkan memberikan kesempatan kepada narapidana untuk dapat bersosialisasi dengan masyarakat melalui pembinaan, maupun kegiatan-kegiatan yang dilakukan bersama masyarakat. Sehingga nantinya apabila sudah bebas dapat kembali ketengah-tengah masyarakat sebagai bagian dari masyarakat tersebut dan yang tidak kalah pentingnya yaitu dapat memberikan bekal pendidikan serta ketrampilan yang dapat digunakan didalam masyarakat nantinya. Penelitian ini bertujuan untuk mengetahui pelaksanaan- pelaksanaan asimilasi sebagai upaya pembinaan Anak negara di Lembaga Pemasyarakatan Karangasem dan untuk mengetahui kendala-kendala yang dihadapi dalam pelaksanaan asimilasi di Lembaga Pemasyarakatan Karangasem. Tipe penelitian yang dipergunakan dalam penelitian ini adalah penelitian hukum empiris. Pelaksanaan asimilasi di Lembaga Pemasyarakatan Karangasem dilaksanakan dengan cara membaurkan narapidana dengan kehidupan masyarakat yang pembinaannya diarahkan untuk memberikan bekal keterampilan maupun pendidikan serta dijadikan wahana bagi narapidana untuk melakukan sosialisasi dengan kehidupan masyarakat luar. Kendala-kendala yang dihadapi dalam pelaksanaan asimilasi di Lembaga Pemasyarakatan Karangasem antara lain: kurangnya petugas lembaga pemasyarakatan Karangasem yang memiliki pendidikan keahlian dan professional, kurang adanya minat masyarakat yang mengabdi di LP Karangasem, kurangnya petugas pelaksana pembinaan narapidana, tenaga ahli masih kurang seperti psikiater, psikolog, sosiolog, dokter dan lain-lain sesuai dengan kebutuhan teknis operasaional rumah tahanan negara Karangasem.
\end{abstract}

\section{Kata Kunci: Anak Negara; Asimilasi; Lembaga Pemasyarakatan}

\begin{abstract}
Assimilation embodies the correctional principle which requires that prisoners are not separated from the community. This assimilation is given in order to provide guidance for prisoners, provide skills or education for prisoners in order to prepare themselves to live independently in the midst of society after being free to undergo a crime. Assimilation can make it possible for prisoners to be able to socialize with the community through coaching, as well as activities carried out with the community. So that later when it is free it can return to the midst of the community as part of the community and no less important is to be able to provide education and skills that can be used in the community later. This study aims to determine the implementation of assimilation as an effort to foster state's adopted children in Karangasem Penitentiary and to find out the obstacles faced in the implementation of assimilation in Karangasem Penitentiary. The type of research used in this study is empirical legal research. The assimilation at Karangasem Penitentiary was carried out by mixing prisoners with the lives of the people whose guidance was directed to provide skills and education as well as a vehicle for prisoners to socialize with the lives of outside communities. Constraints faced in the implementation of assimilation at the Karangasem Penitentiary include: the lack of Karangasem correctional officers who have expertise and professional education, the lack of interest in the community serving in Karangasem Penitentiary, the lack of prison guiding officers, expert staff is still lacking like psychiatrists, psychologists, sociologists, doctors and others in accordance with the technical operational needs of the Karangasem state detention center.
\end{abstract}

Keywords: Assimilation; Correctional Institutions; State's Adopted Children 


\section{PENDAHULUAN}

Pemasyarakatan di Indonesia bertitik tolak atas landasan filsafat Pancasila sebagai dasar negara dan dasar kehidupan bermasyarakat yang lebih mengutamakan prinsip keserasian, keselarasan, dan keseimbangan baik lahir maupun bathin bagi setiap insan (Arief, 2008). Atas dasar itu pemasyarakatan itu tidak membuat narapidana yang melakukan kejahatan memperoleh balasan karena perbuatannya namun dalam hal ini memberikan pembinaan terhadap narapidana. Narapidana adalah orang yang pada suatu waktu tertentu melakukan pidana, karena dicabut kemerdekaannya berdasarkan keputusan hakim (Panjaitan \& Simorangkir, 1991). Pembinaan dilakukan agar orang yang melakukan tindakan kejahatan yang terbukti bersalah berdasarkan putusan pengadilan yang telah mendapat kekuatan hukum tetap dapat dijatuhkan hukuman pidana berupa penjara atau kurungan didalam RumahTahanan Negara (Rutan) yang bertujuan agar para narapidana mendapat pengayoman, pendidikan, serta bimbingan yang kelak akan berguna untuk menjadi warga negara yang baik dan dapat diterima kembali ditengah-tengah masyarakat.

Salah satu cara yang dapat digunakan dalam pembinaan narapidana dilihat dari tahapan diatas yaitu dapat dilaksanakan melalui kegiatan asimilasi yaitu pembinaan narapidana diluar Lembaga Pemasyarakatan dimana kegiatan ini dapat dilakukan setelah narapidana telah menjalani setengah dari masa pidananya yang sebenarnya. Istilah lembaga pemasyarakatan dapat disamakan dengan resosialisasi dengan pengertian bahwa segala sesuatunya ditempatkan dalam tata budaya Indonesia, dengan nilai-nilai yang berlaku di dalam masyarakat Indonesia (Sudarto, 1986). Hal tersebut juga ditekankan dalam Peraturan Menteri Hukum dan Hak Asasi Manusia Republik Indonesia Nomor M.2.PK.04-10 Tahun 2007 tentang Syarat dan Tata Cara Pelaksanaan Asimilasi, Pembebasan Bersyarat, Cuti Menjelang Bebas, dan Cuti Bersyarat di dalam konsideran menimbang ditegaskan bahwa pembinaan narapidana yang dilaksanakan berdasarkan sistem pemasyarakatan bertujuan untuk mempersiapkan narapidana agar dapat berintegrasi secara sehat dengan masyarakat sehingga berperan kembali sebagai anggota masyarakat yang bebas dan bertanggung jawab. Selain itu, lembaga ini bertujuan untuk mengubah sifat, cara berfikir serta prilaku, proses interaksi edukatif harus dibangun (Cooke, Baldwin, \& Howison, 2008). Untuk mewujudkan tujuan pembinaan tersebut salah satu upaya yang dapat ditempuh adalah dengan melalui pelaksanaan asimilasi, Pembebasan Bersyarat, Cuti Menjelang Bebas, dan Cuti Bersyarat.

Asimilasi mewujudkan prinsip pemasyarakatan yang menghendaki agar narapidana tidak dipisahkan dari masyarakat. Asimilasi ini diberikan dengan tujuan agar dapat memberikan pembinaan bagi narapidana, memberikan ketrampilan atau pendidikan bagi narapidana guna mempersiapkan diri hidup mandiri ditengah masyarakat setelah bebas menjalani pidana. Asimilasi dapat memungkinkan memberikan kesempatan kepada narapidana untuk dapat bersosialisasi dengan masyarakat melalui pembinaan, maupun kegiatan-kegiatan yang dilakukan bersama masyarakat. Sehingga nantinya apabila sudah bebas dapat kembali ketengah-tengah masyarakat sebagai bagian dari masyarakat tersebut dan yang tidak kalah pentingnya yaitu dapat memberikan bekal pendidikan serta ketrampilan yang dapat digunakan didalam masyarakat nantinya.

Selama kegiatan asimilasi narapidana diperkenankan melakukan hubungan dengan masyarakat luar yang dapat dilakukan dengan adanya kegiatan-kegiatan sosial dengan masyarakat seperti kerja bakti dengan masyarakat, berolah raga bersama masyarakat, mengikuti upacara atau peragaan ketrampilan bersama dengan masyarakat. Pelaksanaan program asimilasi yang dilakukan diluar Lembaga Pemasyarakatan memiliki resiko yang besar bagi narapidana itu sendiri maupun masyarakat dimana narapidana tersebut melakukan kegiatan asimilasi. Untuk itu diperlukan adanya persetujuan dengan masyarakat, dan narapidana yang bersangkutan harus memenuhi persyaratan untuk menjalankan program asimilasi.

Pelaksanaan asimilasi diberikan kepada narapidana setelah melalui sidang Tim Pengamat Pemasyarakatan (TPP) jika narapidana telah menjalani setengah dari masa pidananya dan menurut penilaian TPP sudah memenuhi segala persyaratan, maka TPP atas persetujuan Kepala Lembaga Pemasyarakatan dapat mengajukan usulan terhadap narapidana tersebut untuk menjalani proses asimilasi kepada Kantor Wilayah Kementerian Hukum dan HAM. Asimilasi diberikan sebagai realisasi proses pembinaan, yang bertujuan yaitu disamping melindungi masyarakat juga memberikan pembinaan bagi narapidana agar sesudah menjalani masa pidananya mempunyai persiapan kembali ketengah- tengah masyarakat menjadi bagian dari masyarakat tersebut yang mempunyai bekal 
ketrampilan, sehingga dapat berguna bagi kepentingan diri sendiri, keluarga, masyarakat, bangsa, dan negara.

Selain penelitian sekarang ini, penelitian lain yang serupa pernah dilakukan, salah satunya oleh Pambudi, Bahiej, \& Hakim (2016) dimana, pelaksanaan asimilasi di Lembaga Pembinaan Khusus Anak Klas I Kutoarjo dilaksanakan dengan membersihkan lingkungan Lembaga Pembinaan, pengecatan Gedung dan mengatur tempat parkir. Asimilasi juga dilaksanakan dengan kegiatan renang serta kegiatan testimoni. Hambatan yang ditemui ialah kurangnya tenaga ahli, sarana dan prasarana, kesulitan mengurus prosedural asimilasi, belum ada Kerjasama dengan pihak lain, dan sedikitnya anggaran. Asimilasi juga dilaksanakan pada narapidana di Lembaga Pemasyarakatan Kelas IIA Way Hui. Asimilasi dijalankan sesuai prosedur yang diatur dalam Undang-undang. Hambatan yang ditemui ialah masyarakat yang sulit menerima kehadiran narapidana di lingkungannya, lamanya pengurusan berkas untuk memperoleh izin asimilasi, serta kurangnya lembaga kerjasama antara pihak Lembaga Pemasyarakatan dengan pihak ketiga (Arriatama, Siswanto, \& WN, 2019). Pelaksanaan asimilasi narapidana di Lembaga Pemasyarakatan Terbuka Jakarta juga menemui hambatan-hambatan diantaranya jarak tempuh dari Lembaga Pemasyarakatan Terbuka Cinere ke tempat bekerja, pihak penjamin yang menjamin narapidana selama berada di luar lembaga pemasyarakatan, tidak sedikit pihak luar atau masyarakat yang tidak mau mempekerjakan narapidana (Jufri \& Anisariza, 2017).

Berdasarkan latar belakang tersebut di atas, penelitian ini dilakukan untuk mengkaji pelaksanaan asimilasi sebagai upaya pembinaan Anak Negara dan kendala-kendala yang dihadapi dalam pelaksanaan asimilasi tersebut di Lembaga Pemasyarakatan Karangasem. Penelitian ini dilakukan untuk mengetahui pelaksanaan asimilasi dalam pembinaan anak negara di lembaga pemasyarakatan Karangasem sesuai dengan peraturan perundang-undangan yang mengaturnya. Dengan itu, tujuan penelitian ini adalah untuk mengetahui pelaksanaan- pelaksanaan asimilasi sebagai upaya pembinaan Anak negara di Lembaga Pemasyarakatan Karangasem dan untuk mengetahui kendala-kendala yang dihadapi dalam pelaksanaan asimilasi dalam pelaksanaan asimilasi di Lembaga Pemasyarakatan Karangasem.

\section{METODE}

Tipe penelitian yang digunakan adalah penelitian hukum empiris. Penelitian hukum empiris atau disebut juga penelitian hukum sosiologis, yang terdiri dari penelitian terhadap indentifikasi hukum (tidak tertulis) dan penelitian terhadap efektifitas hukum (Soekanto, 2007). Dalam penelitian ini dipergunakan pendekatan sosiologi hukum artinya dalam menelaah permasalahan yang diangkat dengan fakta yang ditunjang dengan pendekatan yuridis. Jenis data yang digunakan ialah bahan hukum primer dan sekunder. Data primer didapatkan melalui wawancara, sedangkan data sekunder didapatkan melalui studi kepustakaan. Setelah data dianalisis, data disajikan secara deskriptif.

\section{HASIL DAN PEMBAHASAN}

\section{Pelaksanaan-Pelaksanaan Asimilasi sebagai Upaya Pembinaan Anak Negara di Lembaga Pemasyarakatan Karangasem}

Sistem pemasyarakatan di Indonesia mengandung arti pembinaan narapidana yang berintegrasi dengan masyarakat dan menuju kepada integritas kehidupan dan penghidupan. Pemasyarakatan sebagai proses bergerak dengan menstimulir timbulnya dan berkembangnya penyesuaian diri dalam lingkungan integritas, sehingga narapidana yang bersangkutan menuju ke arah perkembangan pribadi melalui asosiasinnya sendiri sesuai dengan integritas kehidupan dan penghidupan (Poernomo, 1985).

Terkait dengan hal tersebut Bapak I Wayan Subawa mengatakan bahwa untuk memperlancar proses pemasyarakatan narapidana selama menjalani masa pidananya di Lembaga Pemasyarakatan Karangasem, narapidana diikutsertakan dalam berbagai bentuk kegiatan pembinaan. Pembinaan terhadap narapidana bertujuan untuk menjadikan narapidana sebagai manusia mandiri dan mencegah melakukan perbuatan melawan hukum kembali dan merupakan salah satu usaha untuk menciptakan suasana aman dan tertib, dalam masyarakat, serta mempersiapkan narapidana agar dapat terjun kembali secara sehat ke dalam masyarakat.

Dengan berpegang pada prinsip dasar diatas diharapkan sistem pemasyarakatan dapat mencapai yang utama adalah mencegah pengulangan pelanggar hukum, aktif produktif serta berguna bagi masyarakat dan mampu hidup bahagia didunia dan akhirat (Atmasasmita, 1982). Sehingga sistem 
pemasyarakatan di Indonesia harus diartikani sebagai upaya pembinaan narapidana dan memperlakukan cara baru terhadap narapidana berdasarkan prinsip universal yang sudah berkembang secara internasional. Kegiatan pembinaan dapat dilakukan dengan pembimbingan dan kegiatan lainnya, yang berupa pemberian keterampilan maupun pendidikan pada narapidana. Pembinaan dengan bimbingan yang diprogramkan di dalam Rumah Tahanan Negara dapat dilakukan dengan upaya asimilasi.

Tujuan dari pelaksanaan asimilasi adalah agar narapidana dapat menyesuaikan diri secara sehat terhadap masyarakat setelah menjalani masa pidananya sehingga narapidana dapat berinteraksi dengan baik dengan masyarakat. Hal ini sesuai dengan prinsip pokok pemasyarakatan yang salah satunya dimaksudkan yaitu selama kehilangan kemerdekaan bergerak narapidana harus diperkenalkan dengan masyarakat dan tidak boleh diasingkan dari kehidupan masyarakat. Prinsip yang demikian merupakan koreksi terhadap sistem kepenjaraan yang pernah dianut sebelumnya yaitu narapidana dianggap sebagai seseorang yang jahat dan harus dijauhkan dari kehidupan masyarakat, karena dalam sistem pemasyarakatan narapidana tidak boleh dikucilkan dengan masyarakat. Namun narapidana, didalam Lembaga Pemasyarakatan diberikan pembinaan atau dibimbing dan diperkenalkan kembali kepada kehidupan masyarakat.

Asimilasi merupakan salah satu upaya pembinaan narapidana dengan melibatkan peran serta masyarakat. Dimana bentuk kegiatan asimilasi menurut Keputusan Menteri Kehakiman Republik Indonesia Nomor M.01.PK.04-10 Tahun 1999 Pasal 14 disebutkan bahwa asimilasi dapat dilaksanakan melalui berbagai bentuk kegiatan, yaitu :

a. Bekerja diluar LAPAS yang dapat berupa:

1. Bekerja pada pihak ketiga baik instansi pemerintah, swasta ataupun perorangan;

2. Bekerja mandiri, misalnya menjadi tukang cukur, binatu, bengkel, tukang memperbaiki radio dan lain sebagainya;

3. Bekerja pada lapas terbuka dengan tahap security minimum.

b. Mengikuti pendidikan, bimbingan dan latihan keterampilan di luar LAPAS.

c. Mengikuti kegiatan sosial dan kegiatan pembinaan lainnya seperti:

1. Kerja bakti bersama dengan masyarakat;

2. Berolah raga bersama dengan masyarakat;

3. Mengikuti upacara atau peragaan keterampilan bersama dengan masyarakat.

Bentuk kegiatan asimilasi yang dilaksanakan di Lembaga Pemasyarakatan Karangasem dilaksanakan dengan dua tahap yaitu:

a. Asimilasi didalam Lembaga Pemasyarakatan Karangasem.

Dalam bentuk kegiatan ini narapidana diperkenalkan mengenai keadaan lingkungan Lembaga Pemasyarakatan Karangasem, termasuk petugas dan penghuni lainya,yang dimaksudkan agar narapidana dapat beradaptasi dengan lingkungan Lembaga Pemasyarakatan Karangasem sehingga dapat mempermudah narapidana dalam menjalani hukumanya termasuk dalam bersosialisasi dengan lingkungan Lembaga Pemasyarakatan Karangasem.

b. Asimilasi diluar Lembaga Pemasyarakatan Karangasem.

Bentuk kegiatan ini di Lembaga Pemasyarakatan Karangasem dibagi menjadi dua yaitu :

1. Bekerja pada pihak ketiga

Kegiatan ini dapat dilakukan pada perusahaan atau instansi swasta, pemerintahan maupun perorangan dengan syarat

- Surat permohonan dari perusahaan atau instansi terkait bahwa diperlukan narapidana untuk dipekerjakan diperusahaan atau instansi tersebut dengan persetujuan dari kepala lingkungan dimana perusahaan itu berada.

- Dilampirkan surat izin usaha.

- Dilampirkan berita acara termasuk mengenai perjanjian kerja.

2. Bekerja diluar tembok Lembaga Pemasyarakatan Karangasem

Kegiatan ini dilakukan dengan cara bekerja di kebun yang ada diluar tembok Lembaga Pemasyarakatan Karangasem dimana kebun itu ditanami tebu.Kegiatan ini juga dapat dilakukan dengan mengadakan kegiatan kerja bakti diluar Lembaga Pemasyarakatan Karangasem yang tentunya narapidana yang dipekerjakan harus memenuhi persyaratan yang ditentukan. 
Kendala-Kendala yang Dihadapi dalam Pelaksanaan Asimilasi dalam Pelaksanaan Asimilasi di Lembaga Pemasyarakatan Karangasem

Perkembangan ke arah kemajuan senantiasa diusahakan dari hari ke hari, namun demikian sesuai dengan kondisi yang ada tidaklah sedikit kendala-kendala yang dihadapi. Hal-hal yang menjadi kendala dalam pelaksanaan pembinaan narapidana melalui upaya asimilasi yaitu:

a. Petugas Pelaksana Pembinaan

Keterbatasan jumlah petugas pelaksana pembinaan sangat mempengaruhi kelancaran dalam membimbing dan mengawasi penyelenggaraan pembinaan narapidana termasuk asimilasi. Dalam asimilasi memerlukan pengawasan yang seksama karena narapidana dihadapkan dengan kehidupan masyarakat, sehingga peran petugas Lembaga Pemasyarakatan Karangasem sangat penting dalam memberikan pengawasan terhadap narapidana.

b. Narapidana

Narapidana sebagai pihak yang dibina dalam pelaksanaan asimilasi banyak yang kurang menyadari akan pentingnya pelaksanaan asimilasi. Hal ini antara lain disebabkan karena para narapidana pada umumnya kurang meyadari pentingnya pembinaan di Lembaga Pemasyarakatan Karangasem untuk kehidupan dimasa yang akan datang setelah mereka bebas. Hal ini mengakibatkan narapidana tidak memanfaatkan waktu dan kesempatan yang diberikan oleh petugas pelaksanaan pembinaan kepada mereka dengan sebaik- baiknya, sedangkan pembinaan yang diberikan lebih banyak ditentukan dan diarahkan oleh pihak lembaga. Hal yang mendasari pertimbangan ini antara lain karena memang sarana pembinaan yang ada sangat terbatas, serta segala program pembinaan dan pesertanya ditentukan oleh bimbingan dari Lembaga Pemasyarakatan Karangasem demi ketertiban dan kelancaran tugas, hal ini secara tidak langsung akan mempengaruhi pelaksanaan pembinaan terhadap narapidana di Lembaga Pemasyarakatan Karangasem.

c. Masyarakat

Interaksi narapidana sebagai sebuah hubungan sosial yang menggambarkan keterikatan antara sesama narapidana, narapidana dengan lingkungan dalam Lembaga Pemasyarakatan Karangasem termasuk petugasnya serta adanya interaksi narapidana dengan masyarakat yang terjadi selama proses kehidupan narapidana tersebut menjalani masa pidananya. Hal yang merupakan kendala dalam pelaksanaan pembinaan terhadap narapidana (asimilasi) sesuai dengan hasil wawancara penulis dengan Bapak I Ketut Subagia dan beliau mengatakan bahwa pelaksanaan pembinaan terhadap narapidana (asimilasi) adalah penerimaan masyarakat setempat terhadap narapidana tersebut. Dipertimbangkan unsur masyarakat adalah sesuatu yang rasional dan tepat mengingat bahwa narapidana merupakan anggota masyarakat yang telah melanggar hukum serta nantinya narapidana akan kembali ketengah masyarakat setelah bebas nanti. Banyak diantara mereka yang bersikap sinis terhadap narapidana, akibatnya narapidana tersebut akan merasa kehilangan kepercayaan dari masyarakat, kehilangan akan harga dirinya bahkan akan mengakibatkan kehilangan gairah hidupnya didalam menempuh kehidupan selanjutnya.

Menurut Made Setiawan eks narapidana Lembaga Pemasyarakatan Karangasem mengatakan bahwa narapidana mempunyai reputasi yang jelek ditengah masyarakat. Menyandang status narapidana bagi narapidana merupakan beban sosial yang teramat berat, makanya sebisa mungkin mereka akan merahasiakan status mereka pada orang lain karena menurut mereka masyarakat pada umumnya masih menaruh curiga pada siapapun yang pernah menjadi narapidana (Aksara, 2004).

\section{SIMPULAN DAN SARAN}

\section{Simpulan}

Berdasarkan uraian diatas dapatlah ditarik simpulan sebagai berikut:

1. Pelaksanaan pembinaan anak Negara melalui upaya asimilasi di Lembaga Pemasyarakatan Karangasem dilaksanakan dengan cara membaurkan narapidana dengan kehidupan masyarakat yang pembinaannya diarahkan untuk memberikan bekal keterampilan maupun pendidikan serta dijadikan wahana bagi narapidana untuk melakukan sosialisasi dengan kehidupan masyarakat luar, sehingga nantinya tidak canggung ketika kembali ke tengah-tengah masyarakat. Pelaksanaan asimilasi di Lembaga Pemasyarakatan Karangasem berdasarkan pada Keputusan Menteri Kehakiman Republik Indonesia Nomor 
M.01. PK.04-10 Tahun 1999, dan untuk narapidana yang terkait dengan kasus narkoba khususnya pemakai, maka pembinaan dilakukan secara ketat, sehingga sulit untuk diberikan upaya asimilasi.

2. Kendala-kendala yang dihadapi dalam pelaksanaan asimilasi di Lembaga Pemasyarakatan Karangasem antara lain: kurangnya petugas lembaga pemasyarakatan Karangasem yang memiliki pendidikan keahliandan professional, kurang adanya minat masyarakat yang mengabdi di LP Karangasem, kurangnya petugas pelaksana pembinaan narapidana, tenaga ahli masih kurang seperti psikiater, psikolog, sosiolog, dokter dan lain-lain sesuai dengan kebutuhan teknis operasaional rumah tahanan negara Karangasem.

\section{Saran}

Berdasarkan kesimpulan diatas, adapun saran-saran yang dapat disampaikan sebagai berikut:

1. Kepada Pemerintah disarankan dalam pembinaan narapidana perlu diarahkan kepada pemberian bekal ketrampilan, pendidikan baik jasmani maupun rohani yang nantinya akan digunakan sebagai bekal bagi narapidana untuk mendapatkan atau membuka lapangan pekerjaan setelah keluar dari Rumah Tahanan Negara.

2. Kepada Lembaga Pemasyarakatan disarankan pelaksanaan asimilasi perlu ditingkatkan sebagai wahana bagi narapidana untuk bersosialisasi kembali dengan masyarakat, sehingga nanti tidak merasa canggung dalam pergaulan di masyarakat. dan Pembinaan narapidana yang terkait dengan narkoba (pecandu) harus ada pembedaan penanganan dimana narapidana pecandu narkoba perlu ditempatkan pada tempat yang khusus seperti panti Rehabilitasi sehingga dapat penanganan yang lebih seksama dari psikiater.

3. Kepada narapidana disarankan agar pembinaan oleh Lembaga Pemasyarakatan atau petugas dapat dilaksanakan dengan baik sehingga pembinaan dapat berjalan dengan baik dan berguna bagi narapidana itu sendiri.

\section{DAFTAR PUSTAKA}

Aksara, K. (2004). LPAN Gianyar Dulu dan Kini (Edisi XV).

Arief, B. N. (2008). Bunga Rampai Kebijakan Hukum Pidana. Jakarta: Kencana Prenada Media Group. Arriatama, S., Siswanto, H., \& WN, D. (2019). ANALISIS PELAKSANAAN HAK ASIMILASI NARAPIDANA WANITA (Studi di Lembaga Pemasyarakatan Perempuan Kelas IIa Way Hui Bandar Lampung). Retrieved from https://www.google.com/url?sa=t\&rct=j\&q=\&esrc=s\&source=web\&cd=\&ved=2ahUKEwjU7Y TJytjqAhWHbSsKHTYyCgUQFjAGegQIBxAB\&url=https\%3A\%2F\%2Fjurnal.fh.unila.ac.id\% 2Findex.php\%2Fpidana\%2Farticle\%2Fdownload\%2F1731\%2F1464\&usg=AOvVaw0wJAG_p QPiVmuq4BjIMIsm

Atmasasmita, R. (1982). Strategi Pembinaan Pelanggar Hukum dalam Konteks Penegakkan Hukum di Indonesia. Bandung: Alumni.

Cooke, D. J., Baldwin, P. J., \& Howison, J. (2008). Menyingkap Dunia Gelap Penjara. Jakarta: Gramedia.

Jufri, E. A., \& Anisariza, N. U. (2017). PELAKSANAAN ASIMILASI NARAPIDANA DI LEMBAGA PEMASYARAKATAN TERBUKA JAKARTA. ADIL: Jurnal Hukum, 8(1), 1-26. Retrieved from https://media.neliti.com/media/publications/217392-pelaksanaan-asimilasinarapidana-di-lemb.pdf

Pambudi, S. C., Bahiej, A., \& Hakim, F. L. (2016). Pelaksanaan Asimilasi Bagi Anak di Lembaga Pembinaan Khusus Anak Klas I Kutoarjo (Universitas Islam Negeri Sunan Kalijaga Yogyakarta). https://doi.org/https://doi.org/10.3929/ethz-b-000238666

Panjaitan, P. I., \& Simorangkir, P. (1991). Lembaga permasyarakatan dalam Perspektif Peradilan Agama. Jakarta: Pustaka Sinar Harapan.

Poernomo, B. (1985). Pelaksanaan Pidana Penjara Dengan Sistem Pemasyarakatan. Yogyakarta: Liberty.

Soekanto, S. (2007). Pengantar Penelitian Hukum. Jakarta: Universitas Indonesia. 
Sudarto. (1986). Hukum dan Hukum Pidana. Bandung: Penerbit Alumbi. 